\title{
PARENTING FOR LEFT-BEHIND CHILDREN IN MIGRANT WORKER FAMILIES: A STUDY IN WEST JAVA
}

\author{
Slamet Mulyana ${ }^{1}$ \\ Department of Communication Management, \\ Universitas Padjadjaran (Unpad), Indonesia \\ (Email: mulyanaslamet@yahoo.com) \\ Kismiyati El Karimah ${ }^{2}$ \\ Department of Communication Management, \\ Universitas Padjadjaran (Unpad), Indonesia \\ (Email: miyaelkarimah@yahoo.com) \\ Meria Octavianti ${ }^{3}$ \\ Department of Communication Management, \\ Universitas Padjadjaran (Unpad), Indonesia \\ (Email: meria.octavianti@unpad.ac.id)
}

Accepted date: 10-10-2017

Published date: 11-07-2019

To cite this document: Mulyana, S. Karimah, K. E., \& Octavianti, M. (2019). Parenting System for Left-Behind Children in Migrant Worker Families: A Study in West Java. International Journal of Law, Government, and Communication, 4(15), 252-262.

DOI: $10.35631 / \mathrm{ijlgc} .4150024$

\begin{abstract}
Women's decision to be a migrant worker may cause problems in their domestic functions and roles, including childcare. Children may only be taken care of by a father, not both parents as it should be, or even a member of extended family. The negative impact of labor migration on family, particularly left-behind children, has not been a concern of the authorities of the country. This study sought to describe the parenting system for left-behind children in West Java. It used the Case Study method with Karawang and Bandung Barat Regencies were purposively selected as the population. Data were collected by interviewing and observing 20 key-informants, i.e. the householders of the migrant families. The result showed that parenting in migrant worker families was held by husbands/fathers by providing the best care and education for their children. Still, it is different from how a mother may apply it. In some aspects, the mother's role is irreplaceable, particularly at the early development stage. Occasionally, grandmothers and aunts help the fathers to look after the children in order to reduce the fathers' burden. The study found five types of a father in the father-and-left-behindchildren relationship: (1) an intimate father; (2) a plain, distant father; (3) a strict, authoritative father; (4) a spoiling father; and (5) an indifferent father.
\end{abstract}

Keywords: Migrant Worker, Parenting, Left-Behind Children

\section{Introduction}

The phenomenon of Indonesian migrant workers is always enticing to study year by year as it has a great impact on economic, family, law, society, and so forth. We the authors have given 
a deep concern about it for the past ten years (2006-2016). Some problems, including wifehusband relationship in migrant worker families and human trafficking, have been prominence to review. Several research have even been submitted to the relevant stakeholders as an input to address the never-ending problem.

Statistics show that from the total number of migrant workers of the country, the number of females is far greater than that of males, and it keeps growing. Cited from Puslitfo BNP2TKI (2012), in 2011 there were 3,810,534 Indonesian migrant workers, where 75\% of them are female and $88 \%$ of the female worked in informal sector-mostly housemaids.

Another data on the placement of Indonesian migrant workers from January to April 2015 shows that West Java provides the largest proportion, particularly to the Middle East and Far East (Puslitfo BNP2TKI, 2015). Within the same period, several regencies of West Java were in the top fifteen of the most-sending areas: Indramayu, Cirebon, Cianjur and Karawang (Puslitfo BNP2TKI, 2015).

Being a migrant worker is the only alternative to most people in several regions of West Java in order to deal with their economic situation. Women's decision to be a migrant worker depicts the change in their role in family, from reproduction to production. If the decision is made by the majority of them, subsequently this will inflict internal problems in their families and greatly impact their domestic functions and roles.

One major problem of the migrant worker phenomenon is that the ideal parenting cannot be implemented. Children may only be taken care of by their father, not both parents as it should be, or even their grandparents. In fact, family is the primary educational institution for children. Here parenting takes place. The success of a child in their social relations depends on parenting applied in the family. In general, parenting consists of caring, nurturing, teaching and guiding children.

One of domestic roles of the female is parenting. This role pertains to communication pattern and gender relation between male and female in the family. In a family where the economic responsibility fully addressed to the father, mother's role for upbringing children is dominant. In this case, a mother is fully responsible in domestic sector and father in productive to work on their economic needs. However, it will be different if the mother also contributes to productive sector or so-called plays multiple roles.

In regard to women's decision to be a migrant worker, with their domination of up to $78 \%$, the Head of Central BKKBN Fasli Jalal, as cited from Liputan6.com, stated that:

"This figure is quite alarming as it changes women's roles in families, from housekeepers to breadwinner. This will weaken family structure and function as husband can't afford child-rearing the way the female does. Mother cannot be replaced by any extended family. This cause many household problems, including divorce and children development ${ }^{1} . "$

On the other hand, the decision is also related to family (particularly men) function as significant others (important people nearby). Parents and brothers should be taking care of their

\footnotetext{
${ }^{1}$ Liputan6.com, October 15, 2014 downloaded May 20, 2016
} 
children and sisters. Husband should play their role not only to take care of his wife, but also to earn a living for his family.

The impact of labor migration on family, particularly children, has not been a big concern of the authorities of the country. Until recently, there are no data on the number of children being left behind by their parents who work abroad. There is still not enough research or study on left-behind children and recommendation for their protection. In the most-sending countries, such as the Philippines and Mexico, various researches on the impact of labor migration on children are regularly carried out to find the most suitable treatment to them.

The issue of left-behind children has been the $8^{\text {th }}$ common goal (CG) of West Java, i.e. improving the resilience of family and population. There are three descriptions of the objective: (1) to improve family resilience and family planning program; (2) to improve women empowerment and family economy; and (3) to improve population management. Based on this background, the purpose of this study is to describe (1) the relationship between fathers and the left-behind children in migrant worker families in West Java and (2) the parenting for the left-behind children in migrant worker families in West Java.

\section{Literature Review}

This study is consistently based on the previous research on migrant workers, which were conducted from 2006 to 2009, particularly on the socialization of how to reduce human trafficking in West Java. The background of the study was the high number of illegal migrant workers and trafficking of women and children. In 2010, the authors conducted a study on the public figures' perception of human trafficking policy. From 2012 to 2016, the authors continued to explore this phenomenon by conducting several studies: the campaign of human trafficking policy, cultural constraints in disseminating human trafficking policy, and the symbols used in online prostitution involving migrant workers.

Meanwhile, one of relevant studies on migrant workers, particularly on women migrant labor and its impact on family, is Kenakalan Anak TKI Remaja di Kabupaten Pamekasan Madura 'Juvenile Delinquency of the Children of Indonesian Migrant Workers in Pamekasan Madura' by Hamdalah Widia Astutik (2010). This study shows the impact of migrant labor on child education and the delinquency of migrant workers' children. Their education is not wellequipped. They only go to school and gain nothing. This is indeed the impact of their parents working abroad. Furthermore, they become lazy to learn due to the lack of parental supervision. They assume caregivers are just temporary parents, and their care is not comparable to that of biological parents. As a result, the kids perform delinquency, including skipping school, drinking alcohol, stealing, betting/gambling, speeding and having premarital sex.

The other study is Perilaku Remaja Anak Keluarga TKI di Sukabumi 'Teenage Behavior in Migrant Worker Families in Sukabumi' by Herien Puspita and Shely S. (2011). The study on 47 families indicates that three-fifths of the teenagers suffer a moderate-to-high degree of distress. Almost three-fourths of them live with unsatisfactory achievement. The longer their mothers work abroad, the further aggravated their condition. However, on the other hand, the higher family income can also improve their condition, particularly their learning facilities. This suggest that paradoxical dilemma takes place in migrant worker families. Nevertheless, the families and the children spend a greater social cost than the benefit they get. This circumstance is in line with Brooks (2001) who states that parents, particularly mothers, with less family time are the greatest source of distress in family life. 
The last relevant study is Pola Asuh Ayah dalam Keluarga Migran di Kabupaten Banyuwangi 'Dad Parenting in Migrant Worker Families in Banyuwangi Regency' by Nurul Inayah (2012). This study, which has been published in Conference Proceedings: Annual International Conference on Islamic Studies, shows that the absence of mother, an element of family, for being a migrant worker, leads to her dysfunction in her family that it forces father to play a full role in childcare at home, which offers different model of parenting so it affects child development. Year by year the number of female migrations, particularly for working abroad, grows at a startling pace. Migration has changed knowledge system, value system and norms of life as well as life practices and the lifestyle of a society at large.

\section{Method}

This study used the qualitative approach with case study method. This approach is applied for the purpose of this study is to provide a holistic, systemic discussion and to reveal the meaning of the empirical evidence of parenting for left-behind children in migrant worker families. The method is selected for it is considered relevant to obtain as much data as possible on the subject under study. In this method, a researcher studies data on an individual, a group, or an event to give a complete, deep view on the subject under study (Mulyana, 2001: 201). It intensively/deeply studies the members of the targeted group.

This study was conducted in West Java, specifically in Karawang and Bandung Barat Regencies. The regions were selected purposively, i.e. based on the great number of cases of left-behind children and the unique characteristics of the regions in socio-cultural aspect. Karawang Regency is a red area, a sending area that provides lots of labors, particularly women. While Bandung Regency, including Bandung Barat, is a yellow area in the map of sending areas of West Java.

The key informants of this study were selected purposively. They are the families (husbands and children) of the female migrant workers or the ex-ones. Data were collected by interviewing and observing 20 householders of the migrant worker families. The authors also did a review and documentation based on the theoretical concepts described in the previous section.

\section{Result}

There are two focuses of this research: father-children relationship patterns and parenting in migrant worker families. In an intact family, parents-children relationship and communication is entwined, where the parents hold the responsibility to taking care of the children. This is a bidirectional relationship with a shared understanding of them having the same rights to express opinions, thoughts, information and advice. However, in migrant worker families, things are different. Father, as a single parent, builds various interpersonal relationships with their children.

Physically, a father is biologically and anatomically different from a mother. Biologically, men are superior to women. Men's muscles are stronger than women's. Anatomically, men do not have a womb, while women do so that they can give birth to a child.

In general, the role of women is to take care of the household, from giving birth to a child and raising him/her in family to cooking food and caring their husbands, in order to build a peaceful, prosperous household. On the other hand, men are the breadwinners of their families. These different roles are based on the natural gender differences. Therefore, the main role of childcare should belong to women. However, migrant worker families face different reality. Mothers, 
who should have played the main role of childcare, must be replaced by fathers because they have to leave their children behind for a relatively long time.

All informants of this study had children: half of them had 2 children, six of them one and two of them three. The informants live together with their children in their own homes. Although the informants still have their parents, parents-in-law and other relatives who live not far from them, even some of them live in the same village, the informants decided to live separate from their extended families.

As long as the mothers worked abroad, the role of childcare was played by the fathers. Sometimes they do it alone, sometimes they're assisted by their parents/parents-in-law or even relatives who live nearby. Their activities include Bathing, particularly when their children are still toddlers, preparing school needs and daily meals. They try their best to do all of them alone, without the help of others. Some informants told the difficulties they faced during parenting. They said:

“...the most difficult phase is when the children were still toddlers. It's confusing. But I had no choice. I had to bathe and fed them first, then I could work. Sometimes I had to take them to the paddy fields..."

"...yeah, I had to do it all alone. No need to bother others. It's the risk of wife being a migrant worker. But, after a long time, I'm getting used to it..."

"Now, things are better. At most, I only have to prepare their school needs, meals, allowance. The rest my children can take care of it alone. Things used to be difficult indeed. Sometimes I had to entrust them to my parents-luckily, their home is nearby."

For the husband of a migrant worker and the father of the left-behind children, communicating with them is not an easy thing for the family is not intact and their mother is away for a long time. In such condition, they have several options to interact with them. However, they are not easy to do. Each choice needs a comprehensive understanding of the situation and the characteristics of the family, particularly the children. The followings describe the fatherchildren communication of the informants.

Three informants built a form of communication with their children by building intimacy with them. They try to socialize and instill the values they believed in to develop their children's personalities in ways that make them feel loved and their opinions and feelings valued. They seek to spare some time to talk with the children, for example, during breakfast or lunch or in the evening when they watch TV together. The informants ask the children whether they face any difficulties and try to help the children to solve them as well as seek information about their activities, either from their friends or the children themselves by phone. Clarifying this, informant Nurjaya stated:

"...for me, we have to talk with the children and ask what they want. Yes, I have to understand my kids so that they know that their old man care about them. Sometimes I dig information from my neighbors, sometimes from their friends, or even from the kids themselves..."2

\footnotetext{
${ }^{2}$ An interview with Nurjaya, November 15, 2014
} 
In addition, the informants always sought to support every activity of their kids. They give the kids the freedom to choose what's best for them, listen to them, and involve them in family talk, particularly one concerning the kids' life. The kids are given a chance to manage their life and to develop independent control so that eventually they can be responsible for their own life. Clarifying this, informant Tanto stated:

"...our children are God's gifts, so we have to take care of them. Moreover, their mother is not here. I mean we have to train them to be disciplined and independent. I have heard a scholar in a mosque say so. Practice makes perfect. Yeah, I hope so..."3

However, there are fathers who keep distance from their children. This is the most-represented one. In this case, eight informants consider their wives' decision to work abroad is only a choice and the risk of parenting is a normal thing. As a result, communication with the children runs of the mill as is the case with many other families.

The informants stated that they communicated with their children in certain boundaries as their respective roles and positions. The boundaries they created as parents makes their interaction with their children not intense, as if there is a distance from them. When they talk with the children, for example, either when they have meals or do other joint activities, it looks awkward and there is no form of intimacy like jokes. They only talk important things. This communication behavior is reflected in the following part of an interview with an informant:

\begin{tabular}{|c|c|}
\hline Researcher (R) & : How do you communicate with your children? \\
\hline Informant (I) & : Pardon me, I don't know what you're talking about. \\
\hline $\mathrm{R}$ & : I mean do you often talk with them? \\
\hline I & $\begin{array}{l}\text { : Of course, I talk to them, but not often. They should understand that } \\
\text { I'm their father. They must bear it in their mind so that they will respect } \\
\text { me. }\end{array}$ \\
\hline $\mathrm{R}$ & : So, you don't build intimacy with them? \\
\hline I & $\begin{array}{l}\text { : Yeah, so-so, Sir, just like in any other families. We just talk important } \\
\text { things. They have lots of friends out there. They can talk many things } \\
\text { with friends. }\end{array}$ \\
\hline $\mathrm{R}$ & : When do you usually talk with the children? \\
\hline I & $\begin{array}{l}\text { Sometimes in the morning, during breakfast, because we sometimes } \\
\text { have meals together. Sometimes in the evening when we watch TV. } \\
\text { We only talk important things, for example, about their school life. }\end{array}$ \\
\hline
\end{tabular}

The result also showed that three informants communicated with their children in hard, authoritative ways. They do it because they think that the children must be disciplined since early from home. They think it can be applied in a strict way.

The informants and their children had an awkward interaction and they rarely talked to each other. As a parent, they discipline their children in a hard way - the way they think right, and

\footnotetext{
${ }^{3}$ An interview with Tanto, Desember 21, 2014
} 
they don't really care about the needs and desires of the children. The children's opinion is not really heard, and sometimes if the children express it, it is considered a non-compliance attitude. This kind of interaction is illustrated in Iwan's statement as follow:

"...As a father, I've got to be firm to my children. They must learn the hard way so that they will understand and obey me. Talking with my children is not really important. The most important is that they follow my lead. If I don't do it this way, I will face difficulties. They may be insolent, dissident and rebellious. I used to be taught by my parents in this way..."4

In addition, they imposed rules that tend to restrain and punish the children at their homes. The informants also often dictate the children, force them to obey, and don't provide choices for them. They rarely communicate and discuss with their children. They even think that this is the right thing to do that they don't need to ask their children's consideration of all decisions for the children's life. They even perform physical punishment to make their children behave well. The imposition of the rules is described in Sukra's statement as follow:

"...home rules are a must to discipline the kids. They have to obey what we the parents say. If they do mistakes, if it is necessary, they have to be punished. If their delinquency has crossed the line, it's not a big deal to hit them to make them give up..."

\section{Discussion}

Based on the findings of the research, in this section the authors seek to discuss the relationship patterns between the fathers and the left-behind children. The patterns lead to the parenting systems applied by the fathers to their children during the absence of the mothers due to working abroad for a long time.

\section{Relationship Patterns Between Fathers and Left-Behind Children}

The absence of wife/mother, an element of family, due to working abroad for a long time, cause the family to be unstable. The stability of a family may take place if the relationship between husband/father and wife/mother, between father and children, and between mother and children is harmonious. Sociologically, family is a physical and spiritual relationship between each of its structures, i.e. mother, father and children, with mutual expectations (Djamarah, 2002: 18). Thus, in family, there is a functional relationship between its members to realize the expectations. If a family loses one of its elements, it is certain that the family will be unstable and no longer ideal.

Based on the findings, there are five kinds of fathers in father-and-left-behind-children relationship: (1) an intimate father; (2) a plain, distant father; (3) a strict, authoritative father; (4) a spoiling father; and (5) an indifferent father.

\section{An Intimate Father}

A form of communication of the informants is building intimacy with their children. They try to socialize and instill the values they believe in to develop their children's personalities in ways that make them feel loved and their opinions and feelings valued. They also apply family rules firmly for the sake of each family member. Nevertheless, they treat the children warmly

\footnotetext{
${ }^{4}$ An interview with Iwan, January 17, 2015

${ }^{5}$ An interview with Sukra, December 20, 2014
} 
and affectionately. They encourage the children to behave well, and they do not focus on criticizing their bad deeds.

They also always try to support their children's activities. They allow the children to decide what's best for them, listen to their standpoint, and involve them in family talk about the children's life. The kids are given the opportunity to manage their life and to develop independent control so that eventually they can be responsible for their own life. Furthermore, fathers who build a good relationship with their children are educated, knowledgeable people who know how to perform parenting at home. This is closely correlated to their high level of education and social life.

\section{A Plain, Distant Father}

In most migrant worker families in Karawang Regency, interacting with and taking care of children is a condition that must be endured by a husband whose wife works abroad. Biologically, the closeness of father with the children has a different degree from that of mother. Mother, who conceives and gives birth to the children, has emotional closeness with the children, whereas father tends to keep distance from them in their daily life.

Communication behavior of a plain, distant father is widely represented by the informants. For them, their wives' decision to work abroad is only a choice and the risk of parenting is a normal thing. As a result, communication with the children runs of the mill as is the case with many other families.

The informants said that they communicated with their children in certain boundaries as their respective roles and positions. The boundaries they created as parents make their interaction with their children not intense, as if there is a distance from them. When they talk with the children, for example, either when they have meals or do other joint activities, it looks awkward and there was no form of intimacy like jokes. They only talk important things.

\section{A Strict, Authoritative Father}

There are informants who communicate with their children in hard, authoritative ways. They do it because they think that the children must be disciplined since early from home. They think it can be applied in a strict way.

The informants and their children have an awkward interaction and they rarely talk to each other. As a parent, they discipline their children in a hard way - the way they think right, and they don't really care about the needs and desires of the children. The children's opinion is not really heard, and sometimes if the children express it, it is considered a non-compliance attitude.

In addition, the informants impose home rules that tend to restrain and punish the children. They also often dictate the children, force them to obey, and don't provide choices for them. They rarely communicate and discuss with their children. They even think that this is the right thing to do that they don't need to ask their children's consideration of all decisions for the children's life. They even perform physical punishment to make their children behave well.

\section{A Spoiling Father}

Overwhelming affection to children often has a counter-productive effect on the development of their personality, attitude and behavior. There are informants who excessively fulfill children's need of affection. 
In day-to-day activities, their involvement in their children's life is overwhelming. They only set small boundaries for their kids. They often allow the kids to do whatever they want to achieve their goals. They do not warn the kids the danger of things and rarely give guidance to the kids. They assume that least restrictions can make the kids creative and confident. However, this loose supervision and inadequate family talk will only make the children spoiled and dependent.

\section{An Indifferent Father}

It seems that some informants don't really care about parenting for their children and their development during the absence of their wives. They rarely interact with the children because the children spend most of their time with their extended family and live with their grandparents or aunts.

These informants don't think they have to pay much attention to parenting and upbringing because their extended family will take over the responsibility. In their daily life, they are busy with their own stuff, including cheering their selves up to overcome the loneliness for being left by their wives.

\section{Parenting for Left-Behind Children}

Based on fathers-and-left-behind-children relationship above, there are three types of parenting in migrant worker families: (1) collective parenting; (2) mix parenting; and (3) independent parenting.

\section{Collective Parenting}

This type means that the parenting is the responsibility of all family members. Here, a husband involves his and her wife's extended families to take care of the children and to be responsible for their development. Children even spend most of their time with their grandmothers or aunts. They rarely stay with their father. In this condition, parenting can run quite smooth, and children's development is adequately monitored by extended family members. This kind of parenting is usually performed by a migrant worker family who lives not far from their extended family, particularly grandmothers or aunts.

\section{Mix Parenting}

This second type of parenting is performed by father and extended family in a balanced way. Children are taken care of by a member or more of extended family during the day until the father is back from work. So, the children mainly live with their father. This type is usually performed by a quite successful family whose wife/mother has worked abroad more than twice. Most of these families have their own houses where the fathers and the children live together.

\section{Independent Parenting}

In this type, parenting is fully performed by the father. This is usually due to the children have been mature enough (juvenile). This type is usually performed by a well-established migrant worker family whose wife/mother has worked abroad more than four times.

\section{Conclusion}

Communication behavior of a husband of a migrant worker is closely correlated to the condition and the situation of his incomplete family due to the absence of his wife for a long time. For him, as a father, communicating with his children is not an easy thing to do since his wife is not there to help him. In such condition, he has several options to interact with his children: being an intimate father, a plain, distant father, an authoritative father, a spoiling father or an indifferent father. However, they are not easy to do. Each option needs a 
comprehensive understanding of the situation and the characteristics of the family, particularly the children.

Meanwhile, parenting is related to the roles of husband/father and wife/mother. This inevitably ends up being held by the husband/father, i.e. the informants. They try to give their bests to take care of and educate their children. On several occasions, particularly when the children are still at the early age, assistance from extended families like grandmothers and aunts are enough to reduce the burden of the informants.

The way a husband raises his children may be different from his wife. In certain functions, mother's role remains indispensable, especially at the early stage of child development or socalled latent phase. It is where a child seeks to grasp who he/she is, and he/she hasn't been an independent individual and cannot make a social interaction yet. At this stage a child cannot be separated from his/her mother. But, in migrant worker families, because of the circumstances, a mother has to leave her family behind. Thus, the children are reared by their father. Nevertheless, there are fathers who cannot cope with the condition of the children. In the long run, this will affect the children's development and emotional stability.

\section{References}

Astuti, Tri Marhaeni Pudji. (2005). Universitas Negeri Semarang, Disertasi Program Doktor Ilmu Budaya (Antrologi) Universitas Gadjah Mada. Redefinisi Eksistensi Perempuan Migran: Kasus Migran Kembali di Godong, Grobogan Jawa Tengah.

Bungin, Burhan. (2006). Sosiologi Komunikasi. Jakarta: Kencana Prenada Media Group.

Djamarah, Syaiful Bahri. (2004). Pola Komunikasi Orangtua \& Anak Dalam Keluarga. Jakarta: Rineka Cipta.

Effendy, Onong Uchayana. (2003). Ilmu, Teori dan Filsafat Komunikasi. Bandung: Citra Aditya Bakti.

Hastuti, Dwi, (2008). Pengasuhan: Teori dan Aplikasinya, Bogor: Departemen Ilmu Keluarga dan Konsumen, Fakultas Ekologi Manusia, Institut Pertanian Bogor.

Herawati, Nurul. (2010), Perlindungan dan Permenuhan Hak-hak Ekonomi Buruh Migran Perempuan. Pamator, Volume 3, Number 2, October 2010.

Hubeis, Aida V.S. (2010). "Keluarga Indonesia Abad XXI”. Dalam Aida, V.S. Hubeis. 2010. Pemberdayaan Perempuan dari Masa ke Masa. Bogor: PT. IPB Press.

Inayah, Nurul. (2012). Conference Proceedings: Annual International Conference on Islamic Studies. Model Pola Asuh Ayah dalam Keluarga Migran Di Kabupaten Banyuwangi.

Miller, R. S. \& Perlman, D. (2009). Intimate relationships, (5th Ed.). Boston: McGraw Hill Publishing.

Mulyana, Deddy. (2002). Metodologi Penelitian Kualitatif. Bandung: PT Remaja. Rosdakarya.

Nurhayati. (2012). Hubungan Pola Komunikasi dan Kekuatan Keluarga Terhadap Perilaku Seksual Berisiko Pada Remaja di Wilayah Desa Tridaya Sakti Kecamatan Tambun Selatan Kabupaten Bekasi.

Nazir, Moh. (2003). Metode Penelitian. Jakarta: Ghalia Indonesia.

Pusat Penelitian dan Pengembangan Informasi/Puslitfo BNP2TKI, (2012). Laporan Tahunan Kondisi dan Perkembangan Pekerja Migran.

Rosadi, Imam. (2010). Konsekuensi Migrasi Internasional terhadap Relasi Gender (Studi tentang buruh migran internasional yang pulang dari bekerja di luar negeri di Kecamatan Juntinyuat, Kabupaten Indramayu, Jawa Barat. Disertasi Universitas Indonesia. 
Winarti, Murdiyah. (2007). Pusat Kajian Wanita Universitas Pendidikan Indonesia. Kehidupan Sosial-Ekonomi Tenaga Kerja Wanita di Tasikmalaya (Peranan Wanita antara Nilainilai Tradisi dan Perubahan).

Yusuf, Syamsu L. N. (2001). Psikologi Perkembangan Anak dan Remaja. Bandung: Remaja Rosdakarya. 